\title{
Long-term alcohol intake and risk of endometrial cancer in the Nurses' Health Study, 1980-2010
}

\author{
Y Je*,1 I DeVivo ${ }^{2}$ and E Giovannucci ${ }^{2,3}$ \\ ${ }^{1}$ Department of Food and Nutrition, Kyung Hee University, 26 Kyunghee-daero, Dongdaemun-gu, Seoul 130-701, South Korea; \\ ${ }^{2}$ Channing Division of Network Medicine, Department of Medicine, Brigham and Women's Hospital and Harvard Medical School, \\ Boston, MA, USA and ${ }^{3}$ Departments of Nutrition and Epidemiology, Harvard School of Public Health, Boston, MA, USA
}

Background: Previous epidemiologic studies have shown inconsistent results for the association between alcohol intake and endometrial cancer risk. Most of the studies, however, assessed alcohol intake after cancer diagnosis, or measured alcohol intake at baseline only.

Methods: We prospectively examined the association between alcohol intake and endometrial cancer risk in the Nurses' Health Study with 68067 female participants aged 34-59 years in 1980. Alcohol intake was measured several times with validated dietary questionnaires. We calculated cumulative average alcohol intake to represent long-term intakes of individual subjects. Using Cox proportional hazards models, we estimated incidence rate ratios (RRs) and $95 \%$ confidence intervals (Cls) for endometrial cancer risk after controlling for several risk factors simultaneously.

Results: We identified a total of 794 invasive endometrial adenocarcinoma from 1980 to 2010. We found an inverse association among alcohol drinkers (multivariable $\mathrm{RR}=0.81 ; 95 \% \mathrm{Cl}$ : 0.68-0.96) compared with nondrinkers. Women with light alcohol intake of $<5 \mathrm{~g}$ per day ( $\sim$ half drink per day) had a $22 \%$ lower risk of endometrial cancer (multivariable RR $=0.78 ; 95 \% \mathrm{Cl}: 0.66-0.94$ ). Higher intake of alcohol, however, did not provide additional benefits against endometrial cancer: multivariable RRs for $5-14.9 \mathrm{~g}$ ( 1 drink), 15-29.9 g ( 2 drinks), or $\geqslant 30 \mathrm{~g}$ ( $\geqslant 2$ drinks) versus $0 \mathrm{~g}$ per day were $0.88,0.83$, and 0.78 (95\% Cl: 0.49-1.25), respectively. The lower risk among drinkers ( half drink per day) appeared to be stronger for obese women, but no significant interaction by body mass index was found.

Conclusions: This study provides prospective evidence for an inverse association between light alcohol intake ( half drink per day) in the long term and endometrial cancer risk, but above that level no significant association was found.

Endometrial cancer is the most common gynaecological cancer in the United States (De Vivo et al, 2008), and the major risk factors are related to an increased exposure of the endometrium to unopposed oestrogens, along with insulin resistance and hyperinsulinaemia (Kaaks et al, 2002). Lifestyle factors including dietary behaviours that may influence those hormonal factors in the long term may enhance or decrease endometrial cancer risk (Je et al, 2011; Ganmaa et al, 2012; Ollberding et al, 2012; Campagnoli et al, 2013; Dieli-Conwright et al, 2013; Inoue-Choi et al, 2013; Nagle et al, 2013). The recent prospective cohort studies and metaanalysis of coffee consumption and endometrial cancer risk showed that long-term high coffee consumption reduced the risk of endometrial cancer substantially, possibly through the hormonal modulation of coffee consumption (Je et al, 2011; Je and Giovannucci, 2012).

Alcohol intake has been associated with higher levels of oestrogens (Gavaler and Van Thiel, 1992; Hankinson et al, 1995; Madigan et al, 1998; Onland-Moret et al, 2005; Rinaldi et al, 2006;

*Correspondence: Professor Y Je; E-mail: youjinje@khu.ac.kr

Received 14 March 2014; revised 24 April 2014; accepted 24 April 2014; published online 22 May 2014

(c) 2014 Cancer Research UK. All rights reserved 0007-0920/14 
Danforth et al, 2009) and could therefore be expected to increase the risk of endometrial cancer. However, alcohol intake has been shown to improve insulin sensitivity and reduce fasting insulin concentrations as well (Davies et al, 2002). Several epidemiologic studies examined the association between alcohol intake and endometrial cancer risk, showing no association or inverse associations among women who consumed moderate alcohol intake, whereas high alcohol intake showed an increased risk (Friberg et al, 2010; Turati et al, 2010; Sun et al, 2011). Most of the epidemiologic studies were of retrospective design, which measured the past alcohol intake after diagnosis. A few prospective studies have been published, and most of the studies measured alcohol intake at baseline only, which may not represent long-term intakes of individual subjects. As alcohol may affect carcinogenesis over an extended period of time, the cumulative average alcohol intake might provide a better estimate of the long-term effects of alcohol intake.

Our large prospective cohort study, the Nurses' Health Study (NHS), has repeatedly measured intakes of alcoholic beverages, beer, wine, or liquor from validated food frequency questionnaires (FFQs) from 1980, and long-term alcohol intake in grams per day could therefore have been estimated among individuals. To further clarify the role of alcohol among different subgroups, we conducted stratified analyses by several important endometrial cancer risk factors.

\section{MATERIALS AND METHODS}

Study population. The NHS cohort was established in 1976, when 121700 female registered nurses from 11 states in the United States of America aged 30-55 years completed a baseline questionnaire that included items on risk factors for cancer and cardiovascular disease and major medical events. Every 2 years, follow-up questionnaires have been mailed to update information; the follow-up rate has been at least $90 \%$ for each follow-up cycle. Dietary information, which was first asked in 1980 using a validated semiquantitative FFQ, was updated every 2-4 years. We excluded from our analysis women who did not complete the 1980 FFQ (more than 10 blank items or implausibly high or low energy intake $<500$ or $>3500 \mathrm{kcal}$ per day), died or reported any type of cancer (except for non-melanoma skin cancer) before 1980 and had a history of hysterectomy. Women with missing body mass index (BMI, $\mathrm{kg} \mathrm{m}^{-2}$ ) in 1978 or 1980 were also excluded at baseline since obesity is an important risk factor for endometrial cancer (but could re-enter the analysis once information on BMI was available). After these exclusions, 68067 women formed our baseline population. During each follow-up cycle, we censored women who died, were diagnosed with any cancer including endometrial cancer, or had their uterus removed in the previous cycle. For the expanded FFQ assessment after 1980, women with more than 70 blank food items and total caloric intakes $<600$ or $>3500 \mathrm{kcal}$ per day were also excluded.

Ascertainment of endometrial cancer cases. From 1978 forward, women were asked to report on their questionnaires any new diagnosis of endometrial cancer. For woman who reported a diagnosis of cancer, we sought permission to obtain the relevant medical records and pathology report, which provided information on tumour stage, histologic type and grade. Study physicians blinded to all questionnaire data reviewed the documents to verify diagnosis and establish an exact date of diagnosis. Case definition for endometrial cancer was invasive type I epithelial adenocarcinoma (stages IA-IV) diagnosed between 1980 and 2010 $(n=794)$. Noninvasive $(n=355)$, nonepithelial $(n=69)$, or a type of epithelial cancer other than adenocarcinoma $(n=69$; i.e., clearcell, squamous cell, etc.) were not included in the analysis. Stage and grade of tumours included in the analysis was available for $96.6 \%(n=767)$ and $97.6 \%(n=775)$, respectively. Deaths in the cohort were identified by reports from family members and the US Postal Service and a search of the National Death Index; at least 98\% of deaths were ascertained (Stampfer et al, 1984).

Assessment of alcohol and dietary intake. Previous studies have shown that our FFQs have reasonable validity and reproducibility for individual foods (Willett et al, 1985; Salvini et al, 1989). We used information obtained from responses on the eight FFQs assessed in 1980, 1984, 1986, 1990, 1994, 1998, 2002, and 2006. There were nine possible responses for each alcohol intake question, ranging from 'almost never' to ' $6+$ servings per day'. Consumption of beer, wine, and liquor was ascertained in separate items. Each participant was asked how often, on average, she consumed each type of alcoholic beverage over the previous year, using standardised portion of each beverage (a 12-oz bottle or a can of beer, a $4-\mathrm{oz}$ glass of wine, or a $1.5-\mathrm{oz}$ serving of liquor). Alcohol intake (in g per day) was calculated as the sum of the daily number of drinks multiplied by the average alcohol content per type of each alcoholic beverage (beer $12.8 \mathrm{~g}$, light beer $11.3 \mathrm{~g}$, wine $11.0 \mathrm{~g}$, liquor $14.0 \mathrm{~g}$ ), using information obtained from US Department of Agriculture food-composition sources. Alcohol intake as measured by FFQ was highly correlated with intake, as calculated from diet record assessment completed by a sample of study participants (Spearman's $r=0.90)$ (Giovannucci et al, 1991). As a covariate, we calculated glycaemic load (GL) by multiplying the carbohydrate content of each food by its glycaemic index (GI), which is a measure of the relative postprandial blood glucose response per gram of carbohydrates, and then multiplying this value by the frequency of consumption and summing these values for all foods (Salmeron et al, 1997). Total coffee intake as a confounder was assessed since we previously found a significant lower risk of endometrial cancer among high coffee drinkers, and they tended to consume high alcohol as well (Je et al, 2011). The frequency of coffee consumption assessed by the FFQs was converted to cups per day $(237 \mathrm{ml}=$ an $8 \mathrm{oz}$ cup $)$.

Assessment of covariate data. On the 1976 initial questionnaire, we collected information about menopausal status, postmenopausal hormone $(\mathrm{PMH})$ use, oral contraceptive (OC) use, parity, age at last birth, age at menarche, age at menopause, smoking, weight, height, and history of diabetes and hypertension. Information on duration of OC use and parity was asked on each questionnaire through 1984, whereas most other covariate data have been updated on all subsequent biennial questionnaires, except for height and age at menarche. Updated BMI was calculated using height reported at baseline and weight reported at each cycle. Those missing weight in one follow-up cycle had their weight carried forward from the previous cycle, whereas those missing weight for two consecutive cycles were excluded until they reported their weight. Pack-years of smoking were calculated by multiplying the duration and dose of smoking; one pack-year is equivalent to having smoked one pack per day for 1 year.

Statistical methods. For each participant, we calculated persontime from the return date of the 1980 baseline questionnaire to the date of any cancer diagnosis (except non-melanoma skin cancer), death from any causes, hysterectomy, or the end of follow-up, 1 June 2010, whichever came first. To represent the long-term intake for individual subjects as accurately as possible and to reduce random within-person variation, we used cumulative average intake calculated from all available dietary questionnaires up to the start of each 2-year follow-up. For example, dietary data from 1980 FFQ was used for the 1980-1984 follow-up period; the average of 1980 and 1984 intakes was used for the 1984-1986 follow-up period; the average of 1980, 1984, and 1986 intakes were used for 1986-1990 follow-up period; the average of 1980, 1984, 1986, and 
1990 intakes were used for 1990-1994 follow-up period, and so on. We categorised daily alcohol intake into five categories: nondrinkers, $0.1-4.9$ g per day ( $\sim 0.5$ drink per day), 5.0-14.9 g per day ( $\sim 1$ drink per day), 15.0-29.9 g per day ( $\sim 2$ drinks per day), and $\geqslant 30.0 \mathrm{~g}$ per day $(2+$ drinks per day). Cox proportional hazard regression models with follow-up months as a primary time scale were used to estimate incidence rate ratios (RRs) and 95\% confidence intervals (CIs) of developing endometrial cancer in each category of alcohol intake compared with nondrinkers as a reference (Cox, 1972). To control as finely as possible for confounding by age, calendar time, and any possible two-way interactions between these two time scales, we stratified the analysis jointly by age in months and 2-year follow-up cycle. We tested the proportional hazard assumption by including interaction terms between alcohol consumption and duration of follow-up, and the assumption was unlikely to be violated.

In multivariable models, we adjusted the following covariates (see Tables 2-4 for details on how covariates were controlled in multivariable models): BMI, age at menopause, age at menarche, parity and age at last birth, duration of OC use, $\mathrm{PMH}$ use, packyears of smoking, coffee intake, GL, and total energy intake. Linear trends across increasing alcohol intake were tested using the median value of each alcohol intake category as continuous variable to minimise the influence of outliers. To test for a possible curvilinear association between alcohol intake and endometrial cancer risk, we created a quadratic term that squared this linear variable and included it in a separate model with the linear term. Alcoholic beverage types were also evaluated by entering beer, wine, and liquor consumption into a model with or without adjusting for other beverage type, with nondrinkers of a specific beverage type as the reference category.

As sensitivity analyses, we excluded nondrinkers who reported that they had greatly decreased their alcohol drinking during the past 10 years on the baseline 1980 FFQ; allowed $4-8$ years of lag time to examine the possibility that preclinical disease influenced dietary assessment; stopped updating alcohol intake when women were diagnosed with type 2 diabetes; or used baseline alcohol intake only. To assess whether the relationship between alcohol intake and endometrial cancer risk varied across categories of other risk factors, we performed stratified analyses by BMI, smoking status, OC use, menopausal status, and $\mathrm{PMH}$ use (among postmenopausal women). To provide increased power for subgroup analyses, the two upper categories of alcohol intake were combined. Tests of interaction between alcohol categories and potential effect modifiers were assessed by entering the cross-product terms into the model. SAS PROC PHREG with SAS version 9.3 was used for all analyses above (SAS Institute Inc., Cary, NC, USA).

\section{RESULTS}

During 1422149 person-years of follow-up, we ascertained a total of 794 incident cases of invasive endometrial adenocarcinoma among the 68067 women who were eligible for analysis. Among the 794 cases, $385(48.5 \%)$ cases were classified as well differentiated, 277 (34.9\%) as moderately differentiated; and 113 (14.2\%) as poorly differentiated, and the remaining 19 (2.4\%) were not specified. Most of the cases belonged to early stage of endometrial cancer, stages I/II $(n=694,87.4 \%)$, whereas $73(9.2 \%)$ of cases were at stages III/IV and the remaining 27 (3.4\%) were not specified. For the study period, 1980-2010, approximately $77.8 \%$ of the participants reported drinking alcohol, the majority of which were light alcohol drinkers (0.1-4.9 g per day, 54.5\%), whereas the rest of alcohol drinkers consumed moderate (5-14.9 g per day, $29.5 \%)$, high (15-29.9 g per day, $11.3 \%)$, or heavy alcohol $(\geqslant 30 \mathrm{~g}$ per day, 4.7\%). Table 1 shows the characteristics of participants categorised at the midpoint of follow-up (1994), according to cumulative average alcohol intake. Compared with nondrinkers, women who consumed greater amounts of alcohol tended to be smokers, coffee drinkers, consume foods with low GL, and used OCs. In addition, they tended to have a lower prevalence of diabetes, lower BMI, and be nulliparous.

In the age-adjusted model, we found a significant inverse association between alcohol intake and endometrial cancer risk (Table 2). Compared with nondrinkers, women who drank alcohol had a $32 \%$ (95\% CI: $20-43 \%)$ reduction in the risk of endometrial cancer. The age-adjusted RRs for the four upper categories of longterm alcohol intake $(0.1-4.9,5-14.9,15-29.9$, and $\geqslant 30 \mathrm{~g}$ per day) were $0.72,0.67,0.59$, and 0.54 (95\% CI: $0.35-0.85)(P$-value for linear trend $=0.001)$ (Table 2). The inverse associations were attenuated after multivariable adjustment, and BMI was a primary confounder in the multivariable model. Compared with nondrinkers, women who drank alcohol had a 19\% (95\% CI: 4-32\%) risk reduction. The multivariable-adjusted RR for light alcohol intake (0.1-4.9 g per day) remained statistically significant even after the multivariable adjustment (multivariable $\mathrm{RR}=0.78 ; 95 \%$ CI: 0.66-0.94). Above that level of alcohol intake, however, no significant inverse association were found ( $P$-value for a linear trend $=0.66$ ). For the test of a possible curvilinear association, we found no evidence with nonlinear trend, in the age-adjusted as well as the multivariable-adjusted models.

We attempted to exclude from nondrinkers women who reported no alcohol intake in all the FFQs for the study period, but reported that they decreased alcohol intake greatly in the past 10 years at $1980 \mathrm{FFQ}$, considered as former drinkers ( $n=22$ cases), and the multivariable RRs for the five alcohol categories were: 0.79 (95\% CI: 0.66-0.96), 0.89, 0.85, and 0.79, which were similar to the findings from the main analyses. When we stopped updating alcohol intake once women were diagnosed with type 2 diabetes, the multivariable RRs for the alcohol categories were: 0.77 (95\% CI: $0.65-0.93), 0.86,0.82$, and 0.78 . When we allowed $4-7.9$ years of lag time from intake measurement to endometrial cancer incidence ( $n=729$ cases), the significant inverse association with light alcohol drinking was slightly stronger $(\mathrm{RR}=0.74 ; 95 \% \mathrm{CI}$ : $0.61-0.89$ ). When we used baseline alcohol intake only, the inverse association with light alcohol drinking was slightly attenuated but remained statistically significant $(\mathrm{RR}=0.81 ; 95 \% \mathrm{CI}$ : 0.68-0.96).

We also examined endometrial cancer risk in relation to specific type of alcoholic beverages (beer, wine, or liquor). Thirty two per cent of the participants reported drinking beer, $70 \%$ drank wine, and 54\% drank liquor (Table 3). By type of alcoholic beverages, we found no evidence that the benefit of alcohol was restricted to one type of alcoholic beverage after the multivariable adjustment and the other alcoholic beverages. Light alcohol intake from wine, however, tended to be associated with lower risk of endometrial cancer $(\mathrm{RR}=0.85 ; 95 \% \mathrm{CI}$ : 0.71-1.02). A strong nonsignificant inverse association was found among high beer drinkers, but there was a very small number of cases included in that category $(n=3$ cases) $(P$-value for linear trend $=0.08)$. Table 4 shows the associations of alcohol intake and endometrial cancer risk among subgroups stratified by selected endometrial cancer risk factors. Overall, the associations did not vary substantially by smoking status $(P=0.93)$, OC use $(P=0.22)$, menopausal status $(P=0.38)$, or $\mathrm{PMH}$ use among postmenopausal women $(P=0.21)$ (Table 4$)$. The inverse association with light alcohol intake $(<5 \mathrm{~g}$ per day) tended to be stronger among obese (BMI $\geqslant 30 \mathrm{~kg} \mathrm{~m}^{-2}$ ) $(\mathrm{RR}=0.63$; 95\% CI: $0.48-0.83)$, but the interaction by BMI was not statistically significant $(P=0.16)$. We attempted to examine relationships between alcohol intake and endometrial cancer by tumour characteristics using the data on tumour stage and grade. The inverse association with alcohol intake appeared to be stronger for late stage of tumours (stages III/IV) or high grade of tumours (grade III) (Supplementary Table). 
Table1. Age-standardised 1994 (midpoint) participant characteristics, by categories of alcohol intake in US women for the Nurses' Health Study

\section{Category of alcohol intake}

\begin{tabular}{|c|c|c|c|c|c|}
\hline Characteristics & Nondrinkers & $\begin{array}{c}0.1-4.9 \mathrm{~g} \\
\text { per day }\end{array}$ & $\begin{array}{c}5.0-14.9 \mathrm{~g} \\
\text { per day }\end{array}$ & $\begin{array}{c}15-29.9 \mathrm{~g} \\
\text { per day }\end{array}$ & $\begin{array}{l}\geqslant 30 \mathrm{~g} \\
\text { per day }\end{array}$ \\
\hline Age (years) (mean, s.d.) & $59.8(7.3)$ & $58.8(7.2)$ & $59.2(7.1)$ & $60.1(6.9)$ & $61.0(6.6)$ \\
\hline BMI $\left(\mathrm{kg} \mathrm{m}^{-2}\right)$ (mean, s.d.) & $27.4(5.8)$ & $26.8(5.3)$ & $25.4(4.4)$ & $25.1(4.4)$ & $25.3(4.7)$ \\
\hline Total physical activity (MET-h per week) (mean, s.d.) & $17.6(22.2)$ & $19.4(24.0)$ & $21.7(24.6)$ & $21.7(26.9)$ & $19.3(23.0)$ \\
\hline Ever smoked (\%) & 36.5 & 54.6 & 67.4 & 76.9 & 83.8 \\
\hline Diabetes (\%) & 9.0 & 5.6 & 2.9 & 3.0 & 3.7 \\
\hline Hypertension (\%) & 35.1 & 32.8 & 28.7 & 33.0 & 40.0 \\
\hline Age at menarche (years) (mean, s.d.) & $12.4(1.8)$ & $12.4(1.7)$ & $12.5(1.7)$ & $12.6(1.6)$ & $12.6(1.7)$ \\
\hline Oral contraceptive use (\%) & 44.0 & 48.5 & 52.5 & 55.4 & 54.6 \\
\hline Nulliparous (\%) & 6.0 & 5.9 & 6.8 & 7.7 & 9.0 \\
\hline Parity among parous women (mean, s.d.) & $3.1(1.4)$ & $3.2(1.4)$ & $3.1(1.4)$ & $3.1(1.4)$ & $3.1(1.4)$ \\
\hline Age at last birth (years) (mean, s.d.) & $31.8(4.5)$ & $31.5(4.4)$ & $31.3(4.3)$ & $31.2(4.4)$ & $31.0(4.5)$ \\
\hline Postmenopausal (\%) & 76.4 & 77.7 & 78.3 & 80.1 & 80.6 \\
\hline Age at menopause (years) (mean, s.d.) ${ }^{a}$ & $50.2(3.7)$ & $50.2(3.5)$ & $50.2(3.6)$ & $50.1(3.6)$ & $50.0(3.3)$ \\
\hline PMH use $(\%)^{a}$ & 44.7 & 50.8 & 56.8 & 57.2 & 51.2 \\
\hline Coffee intake (cups per day) (mean, s.d.) & $2.0(1.8)$ & $2.4(1.6)$ & $2.7(1.5)$ & $2.7(1.5)$ & $2.7(1.5)$ \\
\hline Dietary glycaemic load (mean, s.d.) & $111.8(35.7)$ & $109.4(33.0)$ & $103.4(32.1)$ & $98.2(31.2)$ & $91.5(31.3)$ \\
\hline Alcohol (g per day) (mean, s.d.) & 0 & $1.8(1.4)$ & $9.0(2.8)$ & $20.9(4.2)$ & $39.7(9.6)$ \\
\hline Beer (g per day) & 0 & $0.3(0.5)$ & $1.4(2.3)$ & $3.4(5.8)$ & $8.5(14.0)$ \\
\hline Wine (g per day) & 0 & $1.0(1.0)$ & $4.3(3.3)$ & $8.8(7.5)$ & $10.5(12.2)$ \\
\hline Liquor (g per day) & 0 & $0.5(0.7)$ & $3.2(3.4)$ & $8.7(7.7)$ & $20.6(15.2)$ \\
\hline
\end{tabular}

Abbreviations: $\mathrm{BMI}=$ body mass index; $\mathrm{MET}-\mathrm{h}=$ metabolic equivalent task hours; $\mathrm{PMH}=$ postmenopausal hormone.

among postmenopausal women.

Table 2. RR of endometrial cancer for categories of cumulative average alcohol intake, follow-up 1980-2010

\section{Category of alcohol intake}

\begin{tabular}{|c|c|c|c|c|c|c|c|}
\hline & Nondrinkers & Drinkers & $\begin{array}{l}0.1-4.9 \mathrm{~g} \\
\text { per day }\end{array}$ & $\begin{array}{l}5.0-14.9 \mathrm{~g} \\
\text { per day }\end{array}$ & $\begin{array}{l}15-29.9 \mathrm{~g} \\
\text { per day }\end{array}$ & $\begin{array}{l}\geqslant 30 \mathrm{~g} \text { per } \\
\text { day }\end{array}$ & $\begin{array}{l}P \text {-value for } \\
\text { trend }\end{array}$ \\
\hline Median (g per day) & 0 & 4.1 & 1.5 & 8.8 & 20.1 & 36.6 & \\
\hline Person-years & 315374 & 1106776 & 603020 & 326213 & 125029 & 52515 & \\
\hline Cases, $n$ & 221 & 573 & 329 & 165 & 58 & 21 & \\
\hline Age-adjusted RR $(95 \% \mathrm{Cl})^{\mathbf{a}}$ & 1.00 (ref.) & $0.68(0.58-0.80)$ & $0.72(0.60-0.86)$ & $0.67(0.55-0.82)$ & $0.59(0.44-0.79)$ & $0.54(0.35-0.85)$ & 0.001 \\
\hline $\begin{array}{l}\text { Multivariable-adjusted RR } \\
(95 \% \mathrm{Cl})^{\mathbf{b}}\end{array}$ & 1.00 (ref.) & $0.81(0.68-0.96)$ & $0.78(0.66-0.94)$ & $0.88(0.71-1.09)$ & $0.83(0.61-1.14)$ & $0.78(0.49-1.25)$ & 0.66 \\
\hline \multicolumn{8}{|c|}{$\begin{array}{l}\text { Abbreviations: } \mathrm{Cl}=\text { confidence interval; } \mathrm{RR}=\text { relative risk. } \\
\text { a Simple model was stratified by age (in months) and } 2 \text {-year follow-up cycle. } \\
{ }^{\mathrm{b}} \text { Multivariable model further adjusted for } \mathrm{BMI} \text { (in } \mathrm{kg} \mathrm{m}^{-2} \text {; continuous), age at menopause (pre-/unknown menopause, }<45,45-46,47-48,49-50,51-52, \text { or } \geqslant 53 \text { years), age at menarche }(<12 \text {, } \\
12 \text {, or }>12 \text { years), parity and age at last birth (nulliparous, } 1-2 \text { and }<30,1-2 \text { and } \geqslant 30,3-4 \text { and }<30,3-4 \text { and } \geqslant 30, \geqslant 5 \text { and }<30, \text { or } \geqslant 5 \text { and } \geqslant 30 \text { years), duration of oral contraceptive use (never } \\
<3,3-5 \text {, or }>5 \text { years), postmenopausal hormone use (premenopausal, postmenopausal, and never used hormones, postmenopausal and past hormone users, postmenopausal and curren } \\
\text { oestrogen hormone users, or postmenopausal and current oestrogen and progesterone hormone users), smoking status (never, }>0-10,>10-20,>20-30,>30-40,>40 \text { pack-years), physical } \\
\text { activity }(<9,9-<18 \text {, or } \geqslant 18 \text { metabolic equivalent task hours per week), history of hypertension (yes or no), cumulative average intakes of total energy (kcal per day, continuous), coffee intake } \\
(<1,1,2-3, \text { or } \geqslant 4 \text { cups per day; } 1 \text { cup }=237 \mathrm{ml}) \text {, and glycaemic load (quartiles). }\end{array}$} \\
\hline
\end{tabular}

\section{DISCUSSION}

In this large prospective cohort study over a 30-year follow-up, we found a significant lower risk of endometrial cancer among alcohol drinkers compared with nondrinkers. Women with light alcohol intake of $<5 \mathrm{~g}$ per day (approximately half drink per day) had a $22 \%$ lower risk of endometrial cancer compared with nondrinkers. Higher intakes of alcohol, however, did not provide additional benefits against endometrial cancer.

The inverse association with light alcohol intake for endometrial cancer risk observed in this cohort is consistent with the results 
Table 3. RR of endometrial cancer risk for categories of cumulative average alcoholic beverage intake, follow-up 1980-2010

Category of alcohol intake

\begin{tabular}{|c|c|c|c|c|c|c|}
\hline & Nondrinkers & Drinkers & $\begin{array}{c}0.1-4.9 \mathrm{~g} \text { per } \\
\text { day }\end{array}$ & $\begin{array}{c}5.0-14.9 \mathrm{~g} \text { per } \\
\text { day }\end{array}$ & $\geqslant 15 \mathrm{~g}$ per day & $\begin{array}{c}P \text {-value for } \\
\text { trend }\end{array}$ \\
\hline \multicolumn{7}{|l|}{ Beer } \\
\hline $\begin{array}{l}\text { Median (g per day) } \\
\text { Person-years } \\
\text { Cases (n) } \\
\text { Age-adjusted RR }(95 \% \mathrm{Cl})^{\mathbf{a}} \\
\text { Multivariable-adjusted RR }(95 \% \mathrm{Cl})^{\mathbf{b}} \\
\text { Multivariable-adjusted RR }(95 \% \mathrm{Cl})^{\mathbf{c}}\end{array}$ & $\begin{array}{c}0 \\
964311 \\
564 \\
1.00 \text { (ref.) } \\
1.00 \text { (ref.) } \\
1.00 \text { (ref.) }\end{array}$ & $\begin{array}{c}0.9 \\
457838 \\
230 \\
0.80(0.68-0.93) \\
0.90(0.76-1.05) \\
0.92(0.78-1.09)\end{array}$ & $\begin{array}{c}0.9 \\
376586 \\
202 \\
0.83(0.70-0.97) \\
0.91(0.77-1.07) \\
0.92(0.77-1.10)\end{array}$ & $\begin{array}{c}7.0 \\
62759 \\
25 \\
0.78(0.52-1.16) \\
0.97(0.65-1.46) \\
0.97(0.64-1.46)\end{array}$ & $\begin{array}{c}28.8 \\
18493 \\
3 \\
0.26(0.08-0.82) \\
0.35(0.11-1.11) \\
0.35(0.11-1.09)\end{array}$ & $\begin{array}{l}0.007 \\
0.08 \\
0.08\end{array}$ \\
\hline \multicolumn{7}{|l|}{ Wine } \\
\hline $\begin{array}{l}\text { Median (g per day) } \\
\text { Person-years } \\
\text { Cases (n) } \\
\text { Age-adjusted RR }(95 \% \mathrm{Cl})^{\mathbf{a}} \\
\text { Multivariable-adjusted RR }(95 \% \mathrm{Cl})^{\mathbf{b}} \\
\text { Multivariable-adjusted RR }(95 \% \mathrm{Cl})^{\mathbf{c}}\end{array}$ & $\begin{array}{c}0 \\
429184 \\
273 \\
1.00 \text { (ref.) } \\
1.00 \text { (ref.) } \\
1.00 \text { (ref.) }\end{array}$ & $\begin{array}{c}1.6 \\
992965 \\
521 \\
0.75(0.64-0.87) \\
0.86(0.74-1.01) \\
0.87(0.73-1.04)\end{array}$ & $\begin{array}{c}1.0 \\
773612 \\
410 \\
0.76(0.65-0.88) \\
0.84(0.72-0.99) \\
0.85(0.71-1.02)\end{array}$ & $\begin{array}{c}8.4 \\
176322 \\
91 \\
0.73(0.57-0.92) \\
0.98(0.76-1.26) \\
0.98(0.74-1.29)\end{array}$ & $\begin{array}{c}22.0 \\
43031 \\
20 \\
0.69(0.44-1.09) \\
0.98(0.61-1.57) \\
1.00(0.62-1.61)\end{array}$ & $\begin{array}{l}0.09 \\
0.58 \\
0.49\end{array}$ \\
\hline \multicolumn{7}{|l|}{ Liquor } \\
\hline $\begin{array}{l}\text { Median (g per day) } \\
\text { Person-years } \\
\text { Cases (n) } \\
\text { Age-adjusted RR }(95 \% \mathrm{Cl})^{\mathbf{a}} \\
\text { Multivariable-adjusted RR }(95 \% \mathrm{Cl})^{\mathbf{b}} \\
\text { Multivariable-adjusted RR }(95 \% \mathrm{Cl})^{\mathbf{c}}\end{array}$ & $\begin{array}{c}0 \\
659255 \\
386 \\
1.00 \text { (ref.) } \\
1.00 \text { (ref.) } \\
1.00 \text { (ref.) }\end{array}$ & $\begin{array}{c}1.3 \\
762895 \\
408 \\
0.84(0.73-0.96) \\
0.94(0.81-1.09) \\
1.02(0.86-1.20)\end{array}$ & $\begin{array}{c}0.9 \\
560416 \\
298 \\
0.83(0.71-0.96) \\
0.90(0.77-1.05) \\
0.96(0.80-1.14)\end{array}$ & $\begin{array}{c}8.0 \\
150753 \\
85 \\
0.93(0.73-1.17) \\
1.17(0.92-1.50) \\
1.25(0.96-1.62)\end{array}$ & $\begin{array}{c}25.7 \\
51726 \\
25 \\
0.69(0.46-1.04) \\
0.92(0.60-1.41) \\
0.98(0.64-1.51)\end{array}$ & $\begin{array}{l}0.15 \\
0.68 \\
0.51\end{array}$ \\
\hline \multicolumn{7}{|c|}{ 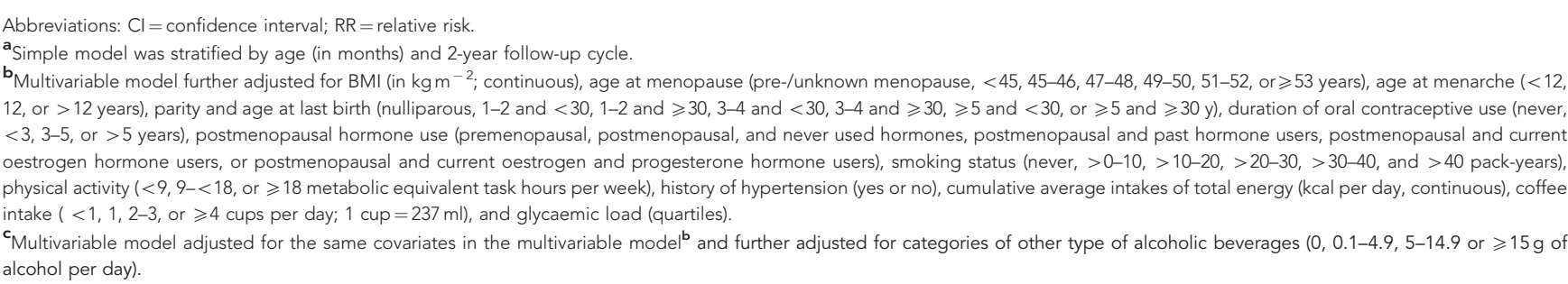 } \\
\hline
\end{tabular}

from the recent meta-analysis (Friberg et al, 2010) of seven prospective studies (Gapstur et al, 1993; Terry et al, 1999; Loerbroks et al, 2007; Kabat et al, 2008; Setiawan et al, 2008; Allen et al, 2009; Friberg and Wolk, 2009). The meta-analysis reported a J-shaped association between risk and number of drinks of alcohol per day: consumption of up to $13 \mathrm{~g}$ of alcohol per day ( one drink) seemed to be associated with a modestly lower risk, whereas exposure to more than two drinks ( $>26 \mathrm{~g}$ of alcohol) per day may increase risk (Friberg et al, 2010). Another meta-analysis (Sun et al, 2011) of 6 prospective studies (Gapstur et al, 1993; Terry et al, 1999; Jain et al, 2000; Loerbroks et al, 2007; Setiawan et al, 2008; Friberg and Wolk, 2009) and 14 case-control studies (La Vecchia et al, 1986; Webster and Weiss, 1989; Shu et al, 1991; Austin et al, 1993; Swanson et al, 1993; Parazzini et al, 1995; Goodman et al, 1997; Newcomb et al, 1997; Jain et al, 2000; Littman et al, 2001; Petridou et al, 2002; Strom et al, 2006; Hosono et al, 2008) included results stratified by the type of alcoholic beverages (beer, wine, and liquor), and revealed that increased risk of endometrial cancer among liquor alcohol drinkers $(\mathrm{RR}=1.22$; 95\% CI: 1.03-1.45), whereas null associations were found with wine and beer consumption (Sun et al, 2011). In our analysis, compared with nondrinkers, the RR in liquor drinkers was 1.02, and RRs in beer and wine drinkers were 0.92 and 0.87 , respectively, and any of the associations by type of alcoholic beverage intake were not statistically significant, suggesting no clear evidence that the benefit of alcohol was restricted to one type of beverage.

Most of prospective studies included in the meta-analyses assessed alcohol intake at baseline only, except for one study that used an average intake with two measurements (Friberg and Wolk, 2009). Since a single measure of alcohol intake did not consider the change in alcohol consumption during the study period, it can lead to non-differential exposure misclassification. Moreover, we cannot rule out the possibility that the lowered RR observed in women drinking up to one drink per day found in the metaanalysis was due to the inclusion of former drinkers in the reference category who were likely to have health problems (Friberg et al, 2010). In our analysis, we used a cumulative average alcohol intake that took into account the past alcohol intake. Some of the women classified by nondrinkers based on several FFQs assessed during the study period reported that they had greatly decreased alcohol intake in the past 10 years, which indicated that they used to be drinkers. To prevent potential bias from 'sick quitters' in the reference category, we attempted to conduct a sensitivity analysis by excluding those women from nondrinkers and the results remained similar to the findings in the main analysis.

A relationship between long-term alcohol intake and risk of endometrial cancer is biologically plausible. In addition to 


\begin{tabular}{|c|c|c|c|c|c|c|c|c|c|c|c|}
\hline \multirow[b]{3}{*}{ Covariates } & \multirow[b]{3}{*}{$\begin{array}{l}\text { Total } \\
\text { no. of } \\
\text { cases }\end{array}$} & \multicolumn{8}{|c|}{ Category of alcohol intake } & \multirow[b]{3}{*}{$\begin{array}{l}P \text {-value } \\
\text { for } \\
\text { trend }\end{array}$} & \multirow[b]{3}{*}{$\begin{array}{l}P \text {-value } \\
\quad \text { for } \\
\text { interaction }\end{array}$} \\
\hline & & \multicolumn{2}{|c|}{$0 \mathrm{~g}$ per day } & \multicolumn{2}{|c|}{$0.1-4.9 \mathrm{~g}$ per day } & \multicolumn{2}{|c|}{$5.0-14.9 \mathrm{~g}$ per day } & \multicolumn{2}{|c|}{$\geqslant 15 \mathrm{~g}$ per day } & & \\
\hline & & $\begin{array}{l}\text { No. } \\
\text { of } \\
\text { cases }\end{array}$ & RR & $\begin{array}{l}\text { No. } \\
\text { of } \\
\text { cases }\end{array}$ & RR $(95 \% \mathrm{Cl})$ & $\begin{array}{c}\text { No. } \\
\text { of } \\
\text { cases }\end{array}$ & RR $(95 \% \mathrm{Cl})$ & $\begin{array}{c}\text { No. } \\
\text { of } \\
\text { cases }\end{array}$ & RR $(95 \% \mathrm{Cl})$ & & \\
\hline \multicolumn{12}{|c|}{ Body mass index $\left(\mathrm{kg} \mathrm{m}^{2}\right)$} \\
\hline $\begin{array}{l}<25 \\
25-29.9 \\
\geqslant 30\end{array}$ & $\begin{array}{l}258 \\
239 \\
297\end{array}$ & $\begin{array}{r}53 \\
52 \\
116\end{array}$ & $\begin{array}{l}1.00 \text { (ref.) } \\
1.00 \text { (ref.) } \\
1.00 \text { (ref.) }\end{array}$ & $\begin{array}{r}93 \\
111 \\
125\end{array}$ & $\begin{array}{l}0.89(0.63-1.27) \\
1.00(0.70-1.41) \\
0.63(0.48-0.83)\end{array}$ & $\begin{array}{l}72 \\
54 \\
39\end{array}$ & $\begin{array}{l}1.05(0.71-1.54) \\
0.99(0.65-1.50) \\
0.80(0.53-1.20)\end{array}$ & $\begin{array}{l}40 \\
22 \\
17\end{array}$ & $\begin{array}{l}0.97(0.61-1.54) \\
0.92(0.54-2.59) \\
0.74(0.42-1.28)\end{array}$ & $\begin{array}{l}0.80 \\
0.77 \\
0.81\end{array}$ & 0.16 \\
\hline \multicolumn{12}{|c|}{ Smoking status } \\
\hline $\begin{array}{l}\text { Never } \\
\text { Ever }\end{array}$ & $\begin{array}{l}403 \\
391\end{array}$ & $\begin{array}{r}153 \\
68\end{array}$ & $\begin{array}{l}1.00 \text { (ref.) } \\
1.00 \text { (ref.) }\end{array}$ & $\begin{array}{l}173 \\
156\end{array}$ & $\begin{array}{l}0.81(0.65-1.02) \\
0.78(0.58-1.05)\end{array}$ & $\begin{array}{r}51 \\
114\end{array}$ & $\begin{array}{l}0.73(0.52-1.02) \\
0.94(0.68-1.29)\end{array}$ & $\begin{array}{l}26 \\
53\end{array}$ & $\begin{array}{l}1.02(0.66-1.60) \\
0.69(0.47-1.02)\end{array}$ & $\begin{array}{l}0.96 \\
0.34\end{array}$ & 0.93 \\
\hline \multicolumn{12}{|l|}{ OC use } \\
\hline $\begin{array}{l}\text { Never user } \\
\text { Ever user }\end{array}$ & $\begin{array}{l}487 \\
305\end{array}$ & $\begin{array}{r}139 \\
82\end{array}$ & $\begin{array}{l}1.00 \text { (ref.) } \\
1.00 \text { (ref.) }\end{array}$ & $\begin{array}{l}197 \\
132\end{array}$ & $\begin{array}{l}0.84(0.67-1.05) \\
0.68(0.51-0.91)\end{array}$ & $\begin{array}{r}102 \\
61\end{array}$ & $\begin{array}{l}1.00(0.76-1.32) \\
0.68(0.47-0.97)\end{array}$ & $\begin{array}{l}49 \\
30\end{array}$ & $\begin{array}{l}0.94(0.65-1.34) \\
0.66(0.42-1.06)\end{array}$ & $\begin{array}{l}0.71 \\
0.32\end{array}$ & 0.22 \\
\hline \multicolumn{12}{|c|}{ Menopausal status } \\
\hline $\begin{array}{l}\text { Premenopausal } \\
\text { Postmenopausal }\end{array}$ & $\begin{array}{r}96 \\
667\end{array}$ & $\begin{array}{r}33 \\
181\end{array}$ & $\begin{array}{l}1.00 \text { (ref.) } \\
1.00 \text { (ref.) }\end{array}$ & $\begin{array}{r}40 \\
281\end{array}$ & $\begin{array}{l}0.83(0.50-1.37) \\
0.78(0.64-0.95)\end{array}$ & $\begin{array}{r}17 \\
138\end{array}$ & $\begin{array}{l}0.84(0.43-1.61) \\
0.84(0.66-1.06)\end{array}$ & $\begin{array}{r}6 \\
67\end{array}$ & $\begin{array}{l}0.64(0.25-1.67) \\
0.79(0.58-1.08)\end{array}$ & $\begin{array}{l}0.45 \\
0.54\end{array}$ & 0.38 \\
\hline \multicolumn{12}{|l|}{ PMH use ${ }^{b}$} \\
\hline $\begin{array}{l}\text { Never } \\
\text { Ever }\end{array}$ & $\begin{array}{l}273 \\
394\end{array}$ & $\begin{array}{l}91 \\
90\end{array}$ & $\begin{array}{l}1.00 \text { (ref.) } \\
1.00 \text { (ref.) }\end{array}$ & $\begin{array}{l}114 \\
167\end{array}$ & $\begin{array}{l}0.75(0.56-1.01) \\
0.81(0.62-1.07)\end{array}$ & $\begin{array}{l}48 \\
90\end{array}$ & $\begin{array}{l}0.89(0.60-1.31) \\
0.83(0.60-1.14)\end{array}$ & $\begin{array}{l}20 \\
47\end{array}$ & $\begin{array}{l}0.74(0.44-1.26) \\
0.86(0.58-1.27)\end{array}$ & $\begin{array}{l}0.66 \\
0.80\end{array}$ & 0.21 \\
\hline $\begin{array}{l}\text { Abbreviations: } \mathrm{Cl}= \\
{ }^{2} \text { Multivariable mod } \\
<45,45-46,47-48, \\
\text { and }<30, \text { or } \geqslant 5 \text { anc } \\
\text { postmenopausal an } \\
\text { (never, }>0-10,>10 \\
\text { average intakes of } \\
\text { b Among postmeno }\end{array}$ & $\begin{array}{l}\text { fidence inte } \\
\text { vas stratifie } \\
50,51-52, \text { c } \\
30 \text { years), d } \\
\text { ast hormone } \\
\text { i > 20-30, } \\
\text { I energy (kc } \\
\text { sal women. }\end{array}$ & $\begin{array}{l}r v a l ; R R= \\
\text { by age } \\
r \geqslant 53 \text { years } \\
\text { uration of } \\
\text { users, pos } \\
30-40,> \\
\text { al per day, }\end{array}$ & $\begin{array}{l}\text { elative risk. } \\
\text { n months) an } \\
\text {, age at men } \\
\text { ral contracept } \\
\text { tmenopausal } \\
40 \text { pack-years } \\
\text { continuous), }\end{array}$ & $\begin{array}{l}\text { d 2-year } f \\
\text { irche }(<12 \\
\text { ive use (ne } \\
\text { and curren } \\
\text {, physical } \\
\text { offee inta }\end{array}$ & $\begin{array}{l}\text { llow-up cycle and fur } \\
12, \text { or }>12 \text { years), par } \\
\text { er, }<3,3-5 \text {, or }>5 \text { yea } \\
\text { oestrogen hormone us } \\
\text { ctivity }(<9,9-<18 \text {, or } \\
\text { e }(<1,1,2-3 \text {, or } \geqslant 4\end{array}$ & $\begin{array}{l}\text { ther adjust } \\
\text { ity and age } \\
\text { ars), postme } \\
\text { sers, or pos } \\
\geqslant 18 \text { meta } \\
\text { cups per do }\end{array}$ & $\begin{array}{l}\text { ed for BMI (in } \mathrm{kg} \mathrm{m}^{-} \\
\text {at last birth (nulliparo } \\
\text { enopausal hormone us } \\
\text { tmenopausal and curre } \\
\text { bolic equivalent task } \\
\text { ay; } 1 \text { cup }=237 \mathrm{ml} \text { ), an }\end{array}$ & $\begin{array}{l}\text { 2; continuo } \\
\text { us, } 1-2 \text { and } \\
\text { se (premenc } \\
\text { ent oestrog } \\
\text { hours per v } \\
\text { d glycaemi }\end{array}$ & $\begin{array}{l}\text { us), age at menopau } \\
<30,1-2 \text { and } \geqslant 30,3 \\
\text { opausal, postmenopau } \\
\text { en and progesterone } \\
\text { veek), history of hyper } \\
\text { c load (quartiles). }\end{array}$ & $\begin{array}{l}\text { e (pre-/unkn } \\
-4 \text { and }<30, \\
\text { sal, and neve } \\
\text { tormone user } \\
\text { tension (yes }\end{array}$ & $\begin{array}{l}\text { wn menopause, } \\
-4 \text { and } \geqslant 30, \geqslant 5 \\
\text { used hormones, } \\
\text {, smoking status } \\
\text { no), cumulative }\end{array}$ \\
\hline
\end{tabular}

exposure to excessive oestrogen levels, chronic hyperinsulinaemia also have a role in endometrial carcinogenesis (Kaaks et al, 2002). Insulin can stimulate the growth of endometrial cells by binding to insulin receptors in the endometrium (Nagamani and Stuart, 1998) and by increasing circulating free insulin-like growth factor-1 through decreasing the levels of insulin-like growth factor-binding protein-1 (Irwin et al, 1993; Weiderpass et al, 2003). Alcohol intake has been associated with reduced fasting insulin concentrations and improved insulin sensitivity (Davies et al, 2002; Joosten et al, 2010), and thus may lower the risk of endometrial cancer by relieving chronic hyperinsulinaemia. A meta-analysis on the relationship between alcohol consumption and risk of type 2 diabetes showed a significant inverse association with $0.1-48 \mathrm{~g}$ of alcohol consumption, whereas no risk reduction was observed in consumers of $\geqslant 48 \mathrm{~g}$ per day (Koppes et al, 2005). In our analysis, the inverse associations with higher amount of alcohol intake were attenuated and became nonsignificant after the multivariable adjustment. Despite the potential benefits of alcohol consumption, heavy alcohol intake may increase the risk of endometrial cancer. Several studies showed a positive association between alcohol intake and oestrogen levels (Gavaler and Van Thiel, 1992; Hankinson et al, 1995; Madigan et al, 1998; Onland-Moret et al, 2005; Rinaldi et al, 2006; Danforth et al, 2009). Although mechanisms by which alcohol drinking increases oestrogen levels are still not completely understood, it has been postulated that alcohol intake stimulates ovarian theca cells to produce androgens through increased $\mathrm{LH}$ secretion, stimulates adrenal cortex to produce androgens through increased ACTH secretion, or increases aromatase activity in the liver, leading to a higher conversion of androgens into oestrogens (Rinaldi et al, 2006). Prolonged exposure of excessive oestrogens may result in endometrial carcinogenesis, through increased mitotic activity of endometrial cells, increased the number of DNA replication errors, and somatic mutations leading to the malignant phenotype (Akhmedkhanov et al, 2001). Owing to the harmful effect of heavy alcohol use, the potential benefits of alcohol consumption on insulin sensitivity and fasting insulin concentrations may be negated to some extent.

We found a stronger inverse association with light alcohol intake among obese women, which is similar to the recent finding in the NIH-AARP Diet and Health Study (Yang et al, 2011). The prospective study showed an inverse association between alcohol intake and endometrial cancer risk among overweight or obese women (BMI $\geqslant 25 \mathrm{~kg} \mathrm{~m}^{-2}$ ), whereas there was some suggestion of higher risks associated with alcohol intake among lean women $\left(\mathrm{BMI}<25 \mathrm{~kg} \mathrm{~m}^{-2}\right) \quad(P$-value for interaction by $\mathrm{BMI}=0.002)$. Although speculative at present, there might be several explanations for the inverse association among obese women. Obese women tend to have insulin resistance and higher levels of insulin compared with lean women, and potential abilities of alcohol 
intake to improve those conditions may have led to reduced risk of endometrial cancer. As overweight or obese postmenopausal women already have high levels of oestrogens, the potential harmful effect of alcohol to elevate oestrogen levels may not be pronounced among those women. On the other hand, lean women who tend to have low insulin resistance and normal fasting insulin levels may be more likely to be affected by increased oestrogens resulting from alcohol intake.

We attempted to examine whether the association between alcohol intake and endometrial cancer risk varied by endometrial cancer characteristics, and observed relatively lower risk of endometrial cancer among alcohol drinkers when the tumours at diagnosis were late stages or high grade of tumours. The results by tumour grade tended to be consistent with those reported in the NIH-AARP diet and health study (Yang et al, 2011). However, the interpretation for the subanalysis should be cautious based on a relatively small number of cases included in each analysis.

An important strength of our study is the prospective design. Retrospective case-control studies, which consist of the majority of literature on this subject, can be prone to recall bias, resulting from differential measurement error among cases and controls in recalling past alcohol intake. As our study assessed alcohol intake before cancer diagnosis, we can avoid the methodological bias. Our study assessed alcohol intake repeatedly with long follow-up period, which allowed us to calculate long-term alcohol intake that may be the most biologically relevant to examine the risk of endometrial cancer. The details of alcohol intake in the several FFQs used in this analysis allowed for the calculation of alcohol in grams per day, thereby enhancing the precision of our exposure. Furthermore, the repeated measurements allowed us to conduct several sensitivity analyses to assess the robustness of the main results. In addition to using cumulative average intake that represents lifetime intake of subjects during the study period, we also attempted to exclude former drinkers before 1980 from the referent nondrinking category to make sure that any potential bias of 'sick quitter' explained the lower risk of endometrial cancer among alcohol drinkers compared with nondrinkers. A relatively large number of cases in our cohort enabled us to conduct subgroup analyses, which is useful to examine the potential mechanisms how alcohol might be associated with endometrial cancer.

Despite these strengths, some limitations of our study must be taken into considerations.

Alcohol drinking is often correlated with smoking and coffee consumption behaviours. In our data, we also found that alcohol drinking was correlated with low BMI and low GL intake. All of the factors such as smoking, coffee consumption, low BMI, and low GL have been associated with low risk of endometrial cancer (Viswanathan et al, 2005; Cui et al, 2011; Je et al, 2011; Zhang et al, 2014). Although we attempted to carefully control for the potential confounders in the multivariable model, residual confounding remains possible. We additionally conducted the analysis by restricting women to those without the factors, and still found similar inverse association with light alcohol intake in the subgroups. Since we had few cases $(n=4$ cases) who consumed very high alcohol intake ( $>45 \mathrm{~g}$ per day) in our cohort, the longterm effects of heavy alcohol use on endometrial cancer risk cannot be investigated. As the recent meta-analysis provided an evidence of an increased risk for endometrial cancer for intakes higher than two alcoholic drinks per day (Friberg et al, 2010), we cannot rule out the possibility of potential harmful effect of heavy alcohol consumption. Finally, our findings from the cohort of US female registered nurses may limit the generalisability, but the homogeneity can minimise some variations by socioeconomic status or other potential confounders.

In conclusion, this study provides prospective evidence for an inverse association between light alcohol intake (approximately half drink per day) in the long term and endometrial cancer risk, but above that level no significant association was found. Our findings may have some public health implications, given the large number of women consuming relatively light alcohol and the increasing incidence of endometrial cancer in Western countries. Further studies examining the association between heavy alcohol intake and endometrial cancer risk should be conducted in large studies with repeated measurements of alcohol intake.

\section{ACKNOWLEDGEMENTS}

We thank the participants and staff of the NHS cohort for their dedication and commitment. We assume full responsibility for the analyses and interpretation of these data. This work was supported by Grant CA87969 from the National Institutes of Health, and Basic Science Research Program through the National Research Foundation of Korea (NRF) funded by the Ministry of Science, ICT \& Future Planning (2014-R1A1A1002736).

\section{CONFLICT OF INTEREST}

The authors declare no conflict of interest.

\section{AUTHOR CONTRIBUTIONS}

All authors have read and approved the final version submitted for publication. YJ and EG developed study concept and design, and contributed to critical revision of the manuscript for important intellectual content. YJ wrote the manuscript and conducted statistical analysis. ID collected the data. YJ, ID and EG contributed to discussion and reviewed the manuscript.

\section{REFERENCES}

Akhmedkhanov A, Zeleniuch-Jacquotte A, Toniolo P (2001) Role of exogenous and endogenous hormones in endometrial cancer: review of the evidence and research perspectives. Ann N Y Acad Sci 943: 296-315.

Allen NE, Beral V, Casabonne D, Kan SW, Reeves GK, Brown A, Green J. Million Women Study Collaborators (2009) Moderate alcohol intake and cancer incidence in women. J Natl Cancer Inst 101(5): 296-305.

Austin H, Drews C, Partridge EE (1993) A case-control study of endometrial cancer in relation to cigarette smoking, serum estrogen levels, and alcohol use. Am J Obstet Gynecol 169(5): 1086-1091.

Campagnoli C, Abba C, Ambroggio S, Brucato T, Pasanisi P (2013) Life-style and metformin for the prevention of endometrial pathology in postmenopausal women. Gynecol Endocrinol 29(2): 119-124.

Cox DR (1972) Regression models and life tables. J R Stat Soc 34: 187-220.

Cui X, Rosner B, Willett WC, Hankinson SE (2011) Dietary fat, fiber, and carbohydrate intake in relation to risk of endometrial cancer. Cancer Epidemiol Biomarkers Prev 20(5): 978-989.

Danforth KN, Eliassen AH, Tworoger SS, Missmer SA, Barbieri RL, Rosner BA, Colditz GA, Hankinson SE (2009) The association of plasma androgen levels with breast, ovarian, and endometrial cancer risk factors among postmenopausal women. Int J Cancer 126(1): 199-207.

Davies MJ, Baer DJ, Judd JT, Brown ED, Campbell WS, Taylor PR (2002) Effects of moderate alcohol intake on fasting insulin and glucose concentrations and insulin sensitivity in postmenopausal women: a randomized controlled trial. JAMA 287(19): 2559-2562.

De Vivo I, Persson I, Adami HO (2008) Endometrial cancer. In: Adami HO, Hunter D, Trichopoulos D (eds Textbook of Cancer Epidemiology. 2nd edn pp 468-493. Oxford University Press: New York, NY, USA.

Dieli-Conwright CM, Ma H, Lacey Jr JV, Henderson KD, Neuhausen S, Horn-Ross PL, Deapen D, Sullivan-Halley J, Bernstein L (2013) Long-term 
and baseline recreational physical activity and risk of endometrial cancer: the California Teachers Study. Br J Cancer 109(3): 761-768.

Friberg E, Orsini N, Mantzoros CS, Wolk A (2010) Alcohol intake and endometrial cancer risk: a meta-analysis of prospective studies. Br J Cancer 103(1): $127-131$.

Friberg E, Wolk A (2009) Long-term alcohol consumption and risk of endometrial cancer incidence: a prospective cohort study. Cancer Epidemiol Biomarkers Prev 18(1): 355-358.

Ganmaa D, Cui X, Feskanich D, Hankinson SE, Willett WC (2012) Milk, dairy intake and risk of endometrial cancer: a 26-year follow-up. Int J Cancer 130(11): 2664-2671.

Gapstur SM, Potter JD, Sellers TA, Kushi LH, Folsom AR (1993) Alcohol consumption and postmenopausal endometrial cancer: results from the Iowa Women's Health Study. Cancer Causes Control 4(4): 323-329.

Gavaler JS, Van Thiel DH (1992) The association between moderate alcoholic beverage consumption and serum estradiol and testosterone levels in normal postmenopausal women: relationship to the literature. Alcohol Clin Exp Res 16(1): 87-92.

Giovannucci E, Colditz G, Stampfer MJ, Rimm EB, Litin L, Sampson L, Willett WC (1991) The assessment of alcohol consumption by a simple self-administered questionnaire. Am J Epidemiol 133(8): 810-817.

Goodman MT, Wilkens LR, Hankin JH, Lyu LC, Wu AH, Kolonel LN (1997) Association of soy and fiber consumption with the risk of endometrial cancer. Am J Epidemiol 146(4): 294-306.

Hankinson SE, Willett WC, Manson JE, Hunter DJ, Colditz GA, Stampfer MJ, Longcope C, Speizer FE (1995) Alcohol, height, and adiposity in relation to estrogen and prolactin levels in postmenopausal women. J Natl Cancer Inst 87(17): 1297-1302.

Hosono S, Matsuo K, Kajiyama H, Hirose K, Suzuki T, Hiraki A, Kawase T, Kidokoro K, Nakanishi T, Hamajima N, Kikkawa F, Tajima K, Tanaka H (2008) Reduced risk of endometrial cancer from alcohol drinking in Japanese. Cancer Sci 99(6): 1195-1201.

Inoue-Choi M, Robien K, Mariani A, Cerhan JR, Anderson KE (2013) Sugarsweetened beverage intake and the risk of type I and type II endometrial cancer among postmenopausal women. Cancer Epidemiol Biomarkers Prev 22(12): 2384-2394.

Irwin JC, de las Fuentes L, Dsupin BA, Giudice LC (1993) Insulin-like growth factor regulation of human endometrial stromal cell function: coordinate effects on insulin-like growth factor binding protein-1, cell proliferation and prolactin secretion. Regul Pept 48(1-2): 165-177.

Jain MG, Howe GR, Rohan TE (2000) Nutritional factors and endometrial cancer in Ontario, Canada. Cancer Causes Control 7(3): 288-296.

Jain MG, Rohan TE, Howe GR, Miller AB (2000) A cohort study of nutritional factors and endometrial cancer. Eur J Epidemiol 16(10): 899-905.

Je Y, Hankinson SE, Tworoger SS, De Vivo I, Giovannucci E (2011) A prospective cohort study of coffee consumption and risk of endometrial cancer over a 26-year of follow-up. Cancer Epidemiol Biomarkers Prev 20(12): 2487-2495.

Je Y, Giovannucci E (2012) Coffee consumption and risk of endometrial cancer: findings from a large up-to-date meta-analysis. Int J Cancer 131(7): 1700-1710.

Joosten MM, Grobbee DE, van der A DL, Verschuren WM, Hendriks HF, Beulens JW (2010) Combined effect of alcohol consumption and lifestyle behaviors on risk of type 2 diabetes. Am J Clin Nutr 91(6): 1777-1783.

Kaaks R, Lukanova A, Kurzer MS (2002) Obesity, endogenous hormones, and endometrial cancer risk: a systematic review. Cancer Epidemiol Biomarkers Prev 11(12): 1531-1543.

Kabat GC, Miller AB, Jain M, Rohan TE (2008) Dietary intake of selected B vitamins in relation to risk of major cancers in women. Br J Cancer 99(5): 816-821.

Koppes LLJ, Dekker JM, Hendriks HF, Bouter LM, Heine RJ (2005) Moderate alcohol consumption lowers the risk of type 2 diabetes: a meta-analysis of prospective observational studies. Diabetes Care 28(3): 719-725.

La Vecchia C, Decarli A, Fasoli M, Gentile A (1986) Nutrition and diet in the etiology of endometrial cancer. Cancer 57(6): 1248-1253.

Littman AJ, Beresford SA, White E (2001) The association of dietary fat and plant foods with endometrial cancer (United States). Cancer Causes Control 12(8): 691-702.

Loerbroks A, Schouten LJ, Goldbohm RA, van den Brandt PA (2007) Alcohol consumption, cigarette smoking, and endometrial cancer risk: results from the Netherlands Cohort Study. Cancer Causes Control 18(5): 551-560.

Madigan MP, Troisi R, Potischman N, Dorgan JF, Brinton LA, Hoover RN (1998) Serum hormone levels in relation to reproductive and lifestyle factors in postmenopausal women (United States). Cancer Causes Control 9(2): 199-207.

Nagamani M, Stuart CA (1998) Specific binding and growth-promoting activity of insulin in endometrial cancer cells in culture. Am J Obstet Gynecol 179(1): 6-12.

Nagle CM, Olsen CM, Lbiebele TI, Spurdle AB, Webb PM (2013) Glycemic index, glycemic load and endometrial cancer risk: results from the Australian National Endometrial Cancer study and an updated systematic review and meta-analysis. Eur J Nutr 52(2): 705-715.

Newcomb PA, Trentham-Dietz A, Storer BE (1997) Alcohol consumption in relation to endometrial cancer risk. Cancer Epidemiol Biomarkers Prev 6(10): 775-778.

Ollberding NJ, Lim U, Wilkens LR, Setiawan VW, Shvetsov YB, Henderson BE, Kolonel LN, Goodman MT (2012) Legume, soy, tofu, and isoflavone intake and endometrial cancer risk in postmenopausal women in the multiethnic cohort study. Natl Cancer Inst 104(1): 67-76.

Onland-Moret NC, Peeters PH, van der Schouw YT, Grobbee DE, van Gils CH (2005) Alcohol and endogenous sex steroid levels in postmenopausal women: a cross-sectional study. J Clin Endocrinol Metab 90(3): 1414-1419.

Parazzini F, La Vecchia C, D’Avanzo B, Moroni S, Chatenoud L, Ricci E (1995) Alcohol and endometrial cancer risk: findings from an Italian case-control study. Nutr Cancer 23(1): 55-62.

Petridou E, Kedikoglou S, Koukoulomatis P, Dessypris N, Trichopoulos D (2002) Diet in relation to endometrial cancer risk: a case-control study in Greece. Nutr Cancer 44(1): 16-22.

Rinaldi S, Peeters PH, Bezemer ID, Dossus L, Biessy C, Sacerdote C, Berrino F, Panico S, Palli D, Tumino R, Khaw KT, Bingham S, Allen NE, Key T, Jensen MK, Overvad K, Olsen A, Tjonneland A, Amiano P, Ardanaz E, Agudo A, Martinez-García C, Quirós JR, Tormo MJ, Nagel G, Linseisen J, Boeing H, Schulz M, Grobbee DE, Bueno-de-Mesquita HB, Koliva M, Kyriazi G, Thrichopoulou A, Boutron-Ruault MC, Clavel-Chapelon F, Ferrari P, Slimani N, Saracci R, Riboli E, Kaaks R (2006) Relationship of alcohol intake and sex steroid concentrations in blood in pre- and postmenopausal women: the European Prospective Investigation into Cancer and Nutrition (EPIC). Cancer Causes Control 17(8): 1033-1043.

Salmeron J, Manson JE, Stampfer MJ, Colditz GA, Wing AL, Willett WC (1997) Dietary fiber, glycemic load, and risk of non-insulin-dependent diabetes mellitus in women. JAMA 277(6): 472-477.

Salvini S, Hunter DJ, Sampson L, Stampfer MJ, Colditz GA, Rosner B, Willett WC (1989) Food-based validation of a dietary questionnaire: the effects of week-to-week variation in food consumption. Int J Epidemiol 18(4): 858-867.

Setiawan VW, Monroe KR, Goodman MT, Kolonel LN, Pike MC, Henderson BE (2008) Alcohol consumption and endometrial cancer risk: the multiethnic cohort. Int J Cancer 122(3): 634-638.

Shu XO, Brinton LA, Zheng W, Gao YT, Fan J, Fraumeni JF Jr (1991) A population-based case-control study of endometrial cancer in Shanghai, China. Int J Cancer 49(1): 38-43.

Stampfer MJ, Willett WC, Speizer FE, Dysert DC, Lipnick R, Rosner B, Hennekens CH (1984) Test of the National Death Index. Am J Epidemiol 119(5): 837-839.

Strom BL, Schinnar R, Weber AL, Bunin G, Berlin JA, Baumgarten M, DeMichele A, Rubin SC, Berlin (2006) Case-control study of postmenopausal hormone replacement therapy and endometrial cancer. Am J Epidemiol 164(8): 775-786.

Sun Q, Xu L, Bo Zhou, Wang Y, Jing Y, Wang B (2011) Alcohol consumption and the risk of endometrial cancer: a meta-analysis. Asia Pac J Clin Nutr 20(1): 125-133.

Swanson CA, Wilbanks GD, Twiggs LB, Mortel R, Berman ML, Barrett RJ, Brinton LA (1993) Moderate alcohol consumption and the risk of endometrial cancer. Epidemiology 4(6): 530-536.

Terry P, Baron JA, Weiderpass E, Yuen J, Lichtenstein P, Nyrén O (1999) Lifestyle and endometrial cancer risk: a cohort study from the Swedish Twin Registry. Int J Cancer 82(1): 38-42.

Turati F, Gallus S, Tavani A, Tramacere I, Polesel J, Talamini R, Montella M, Scotti L, Franceshi S, La Vecchia C (2010) Alcohol and endometrial cancer risk: a case-control study and a metaanalysis. Cancer Causes Control 21(8): 1285-1296.

Viswanathan AN, Feskanich D, De Vivo I, Hunter DJ, Barbieri RL, Rosner B, Colditz GA, Hankinson SE (2005) Smoking and the risk of endometrial cancer: results from the Nurses' Health Study. Int J Cancer 114(6): 996-1001. 
Webster LA, Weiss NS (1989) Alcoholic beverage consumption and the risk of endometrial cancer. Cancer and Steroid Hormone Study Group. Int J Epidemiol 18(4): 786-791.

Weiderpass E, Brismar K, Bellocco R, Vainio H, Kaaks R (2003) Serum levels of insulin-like growth factor-I, IGF-binding protein 1 and 3 , and insulin and endometrial cancer risk. Br J Cancer 89(9): 1697-1704.

Willett WC, Sampson L, Stampfer MJ, Rosner B, Bain C, Witschi J, Hennekens CH, Speizer FE (1985) Reproducibility and validity of a semiquantitative food frequency questionnaire. Am J Epidemiol 122(1): $51-65$.

Yang HP, Gierach GL, Danforth KN, Sherman ME, Park Y, Wentzensen N, Hollenbeck A, Schatzkin A, Brinton LA (2011) Alcohol and endometrial cancer risk in the NIH-AARP diet and health study. Int J Cancer 128(12): 2953-2961.

Zhang Y, Liu H, Yang S, Zhang J, Qian L, Chen X (2014) Overweight, obesity and endometrial cancer risk: results from a systematic review and metaanalysis. Int J Biol Markers 29(1): e21-e29.

This work is published under the standard license to publish agreement. After 12 months the work will become freely available and the license terms will switch to a Creative Commons AttributionNonCommercial-Share Alike 3.0 Unported License.

Supplementary Information accompanies this paper on British Journal of Cancer website (http://www.nature.com/bjc) 